\title{
DETERMINANT OF CASH WAQF NAHDATUL ULAMA (Case of Muslim Students in Indonesia)
}

\author{
Dede Dennis', Abdul Qoyum², Muhammad Rizky Prima Sakti \\ 'Universitas Islam Negeri (UIN) Sunan Kalijaga Yogyakarta \\ Jl. Laksda Adisucipto, Yogyakarta, Indonesia \\ E-mail: dededennis@gmail.com \\ 2Universitas Islam Negeri (UIN) Sunan Kalijaga Yogyakarta \\ Jl. Laksda Adisucipto, Yogyakarta, Indonesia \\ E-mail: qoyum13@gmail.com \\ ${ }^{3}$ Ph.D Candidate, Universiti Teknologi Malaysia (UTM) \\ Jl. Sultan Yahya Petra 54100 Kuala Lumpur, Malaysia \\ E-mail: rizky_islamicfinance@yahoo.com
}

\begin{abstract}
Determinant of Cash Waqf Nahdatul Ulama (Case of Muslim Students in Indonesia). Cash waqf is getting popular in some countries because of its flexibility. Due to that, Bank BTN is supporting the cash waqf through releasing an application called "Mobile Wakaf Uang NU BTN" which is able to be downloaded on App Store. This application is in cooperation with LWP-NU. The purpose of this study is to examine the determinant of cash waqf contribution among Muslim students through Mobile Wakaf Uang NU BTN. Attitude, Islamic religiosity, Islamic egalitarianism and perceived are used as independent variable and its intention of Muslim students in Indonesia to contribute to cash-waqf. The sample of this study are 115 Muslim students who applying Mobile Wakaf Uang NU BTN. This study employs Structural Equation Model (SEM) to verify the determinants of cash waqf contribution and the program used is Smart PLS. This study found that religiosity positively influence on attitude, Islamic egalitarianism, and behavioral intention. While, Islamic egalitarianism as a mediating variable positively influence on intention is rejected, because the $\mathrm{p}$-value is more than $5 \%(0.05)$. Attitude as a mediating variable has a positive influence on intention and perceived ease of use is accepted and perceived ease of use toward intention has a positive influence. In addition, the interesting result of the study showed that the Islamic egalitarianism does not significantly affect on behavioral intention of Muslim students.
\end{abstract}

Keywords: cash waqf; mobile cash waqf of NU BTN; SEM

\begin{abstract}
Abstrak: Ketentuan Wakaf Uang Nahdatul Ulama (Kasus Mahasiswa Islam di Indonesia). Wakaf tunai menjadi populer di beberapa negara karena fleksibilitasnya. Oleh sebab itu, Bank BTN mendukung wakaf tunai dengan merilis aplikasi bernama "Mobile Wakaf Uang NU BTN" yang dapat diunduh di App Store. Aplikasi ini bekerja sama dengan LWP-NU. Tujuan dari penelitian ini adalah untuk menguji faktor-faktor yang menentukan kontribusi wakaf tunai di kalangan mahasiswa muslim melalui Mobile Wakaf NU BTN. Penelitian ini menggunakan beberapa variabel independen yaitu kikap, religiusitas Islam, egalitarianisme Islam dan persepsi. Sedangkan niat mahasiswa muslim di Indonesia untuk berkontribusi pada wakaf uang menjadi variabel dependen. Sampel dari penelitian ini adalah 115 mahasiswa muslim yang menggunakan Mobile Wakaf NU BTN. Penelitian ini menggunakan Structural Equation Model (SEM) untuk menguji determinan dari kontribusi wakaf tunai dan program yang digunakan adalah SmartPLS. Penelitian ini menemukan bahwa religiusitas berpengaruh positif terhadap sikap, egalitarianisme Islam, dan niat perilaku. Sedangkan, hipotesa bahwa egalitarianisme Islam sebagai variabel mediasi berpengaruh positif terhadap niat ditolak, karena p-value lebih dari 5\% (0,05). Sikap sebagai variabel mediasi memiliki pengaruh positif pada persepsi. Selain itu, variabel kemudahan penggunaan juga berpengaruh positif terhadap wakaf tunai. Selain itu, hasil yang menarik lain dari penelitian ini menunjukkan bahwa egalitarianisme Islam tidak secara signifikan mempengaruhi niat perilaku wakaf tunai.
\end{abstract}

Kata kunci: wakaf uang; mobile wakaf uang NU BTN; SEM

\section{Introduction}

Indonesia is a country with the largest Muslim population in the world, more than 87 percent of Indonesian population consider as Muslim.
Whereas for Protestant Christians approximately seven percent, Catholics approximately three percent, and Hindus less than two percent. Interestingly, in some islands of Indonesia, 
Christians or Hindus are the majority, which means that in some areas of Indonesia Muslims are the minority. ${ }^{1}$ Therefore, as the Muslim-majority country, then there must be a real contribution from Islam itself. Thus, the slogan of Islam as a rahmatan lil alamin could be realized by the behavior of Muslims in providing benefits to others. One of the examples of providing benefits to others is through charitable giving.

Charitable giving has been regarded as one of the ways to bringing enormous benefits and prosperity in a society. Furthermore, charitable giving is actually recommended in Islam where a muslim is encouraged to give some of his wealth as a charity. ${ }^{2}$ As al-Qardhâwi postulated that "this behavior is a fundamental part of Islamic teaching as mentioned in many verses of the Qur'an and prophet has said the nobility and importance of almsgiving in Muslim societies."3

In Islamic teaching, charitable giving has four methods. One of them is waqf. ${ }^{4}$ The charitable giving in the form of waqf is an important part of Islamic teachings. It is derived from the Arabic verb waqaf, the word waqf means holding, guarding, or keeping. Waqf is also acharitable action recommended by Prophet Muhammad saw and practiced in the early period of Islam. ${ }^{5}$

The concept of waqf is functioned to keeping or cultivating some property and consecrating its profits to assisting the poor or for other pious intentions. Waqf can be established in many forms depending on its purpose and the nature of outcome. The most general types of waqf are the property and monetary ${ }^{6}$. One of the monetary

${ }^{1}$ USCIRF, U.S. Commission on international religious freedom, Annual Report 2017.

${ }^{2}$ Amirul Faiz Osman, "an analysis of cash waqf participation among young intellectuals," ISBN 978-80-87927-00-7, IISES, 2014.

3 Rahmatina Awaliah Kasri, "Giving behaviors in Indonesia: motives and marketing implications for Islamic charities", Journal of Islamic Marketing, 2013, Vol. 4 No. 3, pp. 306-324.

${ }^{4}$ Amirul Faiz Osman. , "an analysis of cash waqf..., 2014.

5 Ptchay, Anwar Allah, Meera, Ahmed Kameel Mydin dan Saleem Muh Yusuf, "Factors Influencing the Behavioral Intentions of Muslim Employees to Contribute to CashWaqfThrough Salary Deductions" Islamic Economics, Vol. 28, No. 1, 2015, pp: 57-9.

6 Hamid Rizal, dan Hanudin Amin, "Perceived ihsan, Islamic egalitarianism and Islamic religiosity towards charitable giving of cash waqf", Journal of Islamic Marketing , Vol. 8 No. 4 , 2017, pp. 669-685. waqf is cash waqf. Cash waqf had been introduced in the early fifteenth century and it opened a new insight for waqf development, particularly to encourage Muslims in a giving behavior? ${ }^{7}$. The popularity of cash waqf has recently grown rapidly in Muslim communities. As Cizakca said that now so many wealthy Muslims are willing to give their wealth for cash waqf to particular institutions and distributing it for social utilities to the vulnerable community ${ }^{8}$.

Cash waqf is defined as giving of some money in the form of a waqf distribution and then paying based on the certain amount and distributing it to people who are qualified to get the benefits from the return of waqf or it also can be allocated for the community development as well. Nowadays, the management of waqf of cash should involve many agencies to be run efficiently and optimally.

In the course of history, waqf continues to evolve with the pace of changing times with various relevant innovations, such as the form of cash waqf, waqf Intellectual Property Rights (HAKI), and others. In Indonesia itself, this time waqf increasingly received serious attention with the issuance of Law no. 41 year 2004 about waqf and PP. 42 of 2006 on the implementation. To develop a waqf in Indonesia has been established waqf Agency Indonesia. Birth of waqf Indonesia (BWI) is the embodiment of the mandate outlined in Law No. 41 of 2004 on waqf. The presence of BWI, as described in article 47 , is to promote and develop consolidation in Indonesia. For the first time, BWI membership was appointed by the President of the Republic of Indonesia, in accordance with Presidential Decree No.75 / M of 2007 , set in Jakarta, July 13, 2007. The BWI's objective is expected to be a new milestone in rebuilding the waqf system which can contribute optimally in community development.

Islamic banking industries continue to provide various products and facilities to comply the

7 Amirul Faiz Osman, Muh, Mustafa Umar dan Fadhil, Aimin, Factor Influencing Cash Waqf Giving Behavior:a Revised Theory of Planned Behavior, 2015.

${ }^{8}$ Omar Ahmad Kachkar, "Towards the establishment of cash waqf microfinance fund for refugees", ISRA International Journal of Islamic Finance, Vol. 9 No. 1, 2017, p. 81-86. 
needs of its customers. ${ }^{9}$ One of them is PT Bank Tabungan Negara (Persero) Tbk strengthening its commitment to support Gerakan Wakaf Uang Sejuta Nahdliyin (Gerwaku Sena) or Wakaf Money Movement of One Million of Nahdliyin initiated by Nadhatul Ulama (NU) in May 2016 by the release of mobile application of waqf payment. The application called Mobile Wakaf uang NU BTN, is easy for those who are willing to do waqf. ${ }^{10}$

This application appears with a certificate status feature to display a waqf certificate owned by wâqif. The issuance of waqf certificate money does not use stamp and it is delivered by an e-mail to wâqif. To manage the cash waqf, Bank BTN cooperates with Waqf Institution and NU land. NU became a partner of Bank BTN since the signing of a cooperation agreement (PKS) in the last February, because NU has an abundant NU citizen base, at least 85 million people. "The launching of the application is expected to facilitate every Muslims who are willing to contribute in cash waqf.

The study conducted by Rizal and Amin ${ }^{12}$ 'Perceived Ihsan, Islamic Egalitarianism and Islamic religiosity towards charitable giving of cash waqf" found that there are several determinants which influence on cash waqf contribution, namely Perceived Ihsan, Islamic Egalitarianism and Islamic Religiosity and then the study by Sakti' ${ }^{13}$ et al entitled "determinants of cash waqf contribution in Klang Valley and Slangor: A SEM approach revealed that the main determinants that motivate people on the contribution of cash waqf are attitude and social influence. It is reinforced by a study conducted by Osman, Mohammad \& Fadzil" on "factor influencing cash waqf giving behavior: a revised theory

9 http://Syariah.bisnis.com/read/20170218/232/629882/banksyariah-tawarkan-tabungan-wakaf, retrieved on January $19^{\text {th }} 2018$.

${ }^{10} \mathrm{http}$ ://finance.kontan.co.id/news/btn-luncurkan-aplikasipembayaran-wakaf, retrieved on January $19^{\text {th }} 2018$.

11 http://www.btn.co.id/id/content/btn-info/info/berita-btn/ bank-btn-luncurkan-aplikasi-selular-pembayaran-wakaf, retrieved on January $19^{\text {th }} 2018$.

${ }^{12}$ Hamid Rizal, dan Hanudin Amin, Perceived ihsan, Islamic egalitarianism..., pp.669-685.

13 Muh R.P Sakti, Hassanudin Thaker, Abdul Qoyum, and Ibnu Qizam, "Determinants of cash waqf contribution in KlangValley and Slangor: A SEM Approach", Journal of Islamic Monetary Economics and Finance, 2016, Vol. 2, No 1.

${ }^{14}$ Amirul Faiz Osman, Muh, Mustafa Umar dan Fadhil, Aimin, Factor Influencing..., p. 65 of planned behavior" that perceived behavior control, trust and religiosity positively influence intention toward cash waqf giving. While intention is positively influence the cash waqf giving behavior. The present study investigates the role of attitude, Islamic egalitarianism, Islamic religiosity and perceived ease of use on cash waqf contribution through Mobile Wakaf Uang NU BTN. According to the research by Alsamydai ${ }^{5}$ et al., the degree of correlation between the motivating factors of mobile banking services usage is greater than the degree of correlation between impeding factors. This case perceived ease of use is one of the motivating factors.

\section{Theory and Hypotheses Islamic Religiosity and Attitude}

Attitude is one of major factors in Islam and it is very important in Islamic teaching. Osman ${ }^{16}$ defined attitude as the psychological tendency that is expressed from favorable or unfavorable evaluation on a particular entity. In general, the more favorable a person's attitude towards behavior, the more likely it is likely the person will want to engage in the behavior.

If someone has a high sense of religiosity then he/she will automatically behave well. If someone has a good religiosity, it indicates that person would have a good attitude. According to a study conducted by Krysinska et $\mathrm{al}^{17}$ entitled "Measuring Religious Attitudes in Secularized Western European Context:A Psychometric Analysis of the PostCritical Belief Scale.", that a generalized symbolic attitude might be correlated to the changes in the approaches to religion in secularized Western Europe. The research by $G^{G}$ raafland ${ }^{18}$ entitled "Religiosity, Attitude, and the

15 M.J. Alsamyda, S.G.Yassen, H.M. Alnaimi, D.M. Dajani, I.A. Al Qirem, "The Factors Influencing Customer Usage Of Mobile Banking Services In Jordan" International Journal of Business Management \& Research Vol. 4, 2014, Issue 2, p. 63-78.

${ }^{16}$ Amirul Faiz Osman, "an analysis of cash waqf...", IISES, 2014

${ }^{17}$ Karolina Krysinska, K.D Roover, J. Bouwes, Ceulemans, Corveleyn, Duriez, Hutsebaut, Pollefeyt, "Measuring Religious Attitudes in Secularized Western European Context: A Psychometric Analysis of the Post-Critical Belief Scale", The International Journal for the Psychology of Religion, 2014, 24:263-281.

18 Johan Graafland, "Religiosity, Attitude, and the 
Demand for Socially Responsible Products " found that Christian religiosity develops positive attitude upon SR products and also in conformity with the Theory of Planned Behavior, attitude is shown to develop the demand for SR Products. The direct effect toward opposition to torture did not vary across Americans with differing levels of exposure to political discourse, whereas the indirect effect toward support of torture via conservative political alignment was much stronger among Americans highly exposed to political discourse. Among such individuals, the indirect effect was so strong that it completely counteracted the competing direct effect. Based on the theory and a few studies above, the hypothesis is:

H1: Islamic Religiosity positively influence on attitude.

\section{Islamic Religiosity and Islamic Egalitarianism}

While in the surah of al-Hujurât [49]: 13, promoted egalitarianism of equality amongst people in the world. A study conducted by Collet and Lizardo"19 entitled "A Power-Control Theory Of Gender And Religiosity" showed that women raised by high-SES mothers are less religious than women raised by low education mothers, but mother's socioeconomic status has little effect on men's chances of being irreligious and father's socioeconomic status has a negligible effect on the gender difference in religiosity. In addition, the study by Glenwright and Fowler ${ }^{20}$ entitled "Implications of Egalitarianism and Religiosity on Relationship Satisfaction" found that there is a positive relationship between relationship satisfaction and egalitarianism, and found that there is a negative relationship between egalitarianism and various measures of religiosity and then found a weak negative correlation between religiosity and relationship satisfaction. The more positive religiosity of someone the greater is the Islamic egalitarian.

Demand for Socially Responsible Products", Journal Business Ethics, 2017, 144:121-138,

19 J.L ,Collett, Lizardo, Omar A Power-Control Theory Of Gender And Religiosity, (University of Notre Dam, 2008), p. 89.

20 B.J. Glenwright, \& D.M. Fowler, "Implications of Egalitarianism and Religiosity on Relationship Satisfaction", Interpersona: An International Journal on Personal Relationships, 2013, Vol. 7, No. 2, pp, , 215-226.
Therefore, based on the statement above the hypothesis is:

H2: Islamic Religiosity positively influence on Islamic egalitarianism

\section{Islamic Religiosity and Behavioral Intention}

Shafiq Falah Alwaneh stated that a primary motivation in Islam is Iman (faith). Iman functions are to maintain the behavior and evaluate the conduct from bad or good. In a study conducted by Mochtar" entitled "Perceptions of Universiti Sains Malaysia Muslim Staff on Factors Influencing their Intention to Perform Cash Waqf" showed that the factor of religiosity has the highest score which means that the factor of religiosity plays an important role in participation in cash waqf. A study conducted by Osman, Mohammed \& Fadzil revealed that religiosity has a positive effect on intention toward cash waqf distribution. On the other hand, the study by Sakti et al. entitled "determinants of cash waqf contribution in Klang Valley and Selangot: SEM Approach" showed that the obligation of religion is not influence toward cash waqf contribution. In the present study will investigate whether religiosity has an effect on charitable giving of cash waqf or not. If a person has a high sense of religiosity then the tendency to do charity behavior due to the command of God will be higher. Therefore, the hypothesis is:

$\mathrm{H}_{3}$ : Islamic religiosity positively influence on behavioral intention

\section{Islamic Egalitarianism and Behavioral Intention}

Nathan defined that egalitarianism as a doctrine that there is an intrinsic value in the equal distribution of intrinsically good things.22 The idea of egalitarianism is rooted from the justice itself. The principle of justice is:

"Each person is to have an equal right to the most extensive basic liberty compatible with a similar liberty for others and social and

${ }^{21}$ Moh Zulfakhairi, Mochtar, "Perceptions of Universiti Sains Malaysia Muslim Staff on Factors Influencing theirIntention to Perform Cash Waqf", Journal of Islamic Studies and Culture, December 2016, Vol. 4, No. 2, pp. 101-109

${ }^{22}$ Hamid Rizal, dan Hanudin Amin, "Perceived ihsan, Islamic egalitarianism...", pp.669-685. 
economic inequalities are to be arranged so that they are both reasonably expected to be to everyone's advantage and attached to positions and offices open to all"23.

In a study conducted by Rizal and Amin entitled "Perceived ihsan, Islamic egalitarianism and Islamic religiosity towards charitable giving of cash waqf" showed a significant relationship between perceived ihsan, Islamic egalitarian and Islamic religiosity on cash waqf contribution. If a person has a feeling that everyone deserves equality and happiness, then will have a tendency to conduct a charity. Therefore, the hypothesis is: H4: Islamic egalitarianism positively influences on Behavioral Intention.

\section{Attitude and Behavioral Intention}

Attitude is regarded as one of the determinants which influence an intention. Osman said that the more favorable a person's attitude towards behavior, the more likely it is likely the person will want to engage in the behavior. According to Fishbein \& Ajzen, attitude toward behavior is defined as an individual's positive or negative feelings (evaluation effect) about performing the target behavior" ${ }^{24}$. The study conducted by Pitchay et $\mathrm{a}^{25}$ entitled "Factors influencing the behavioral intentions of Mulism employees to contribute to cash waqf through salary deductions" found that attitude has a relationship with behavioral intentions of muslim employees, and also found that attitude of muslim employees has more influence compared to subjective norms. In addition, the study conducted by Osman entitled "an analysis of cash waqf participation among young intellectuals" showed that attitude significantly associated with cash waqf participation. Therefore, a suitable hypothesis is:

H5: Attitude positively influences on behavioral intention.

${ }^{23}$ John Rawls, An Egalitarian Theory of Justice. (Cambridge, Mass: Harvard University Press, 1971), p. 99

${ }^{24}$ Osman, Amirul Daiz, Muh, Mustafa Umar dan Fadhil, Aimin, "Factor Influencing Cash Waqf...", p. 77.

${ }^{25}$ Ptchay, Anwar Allah, Meera, Ahmed Kameel Mydin dan Saleem Muh Yusuf, "Factors Influencing the Behavioral..., p: 57-90.

\section{Perceived Ease of Use and Attitude}

The relationship perceived ease of use and attitude in TAM theory has an empirically verification in some IT literatures. Several studies have employed different usage measures and found them consistent with TAM results, so that perceived ease of use has a close correlation to attitude. People would use something that makes their work effortless, which means that they tend to be using anything to make their life much easier. According to the TAM theory, attitude towards using a particular system or technology is determined by perceived ease of $\mathrm{use}^{26}$.

According to the research conducted by Renny, Guritno and Siringoringo ${ }^{27}$, perceived usefulness influence the attitudes towards usability of airlines ticket reservation stronger than perceived ease of use and trust. Suki and Suki ${ }^{28}$ said that perceived usefulness, Perceived Ease of Use and Attitude are jointly responsible in determining the subscribers' intention to use of $3 \mathrm{G}$ mobile service. In addition, the study by Adewole and Odeshi ${ }^{29}$ showed that there is a relationship between perceived ease of use and attitude. According to the theory above, the next hypothesis is:

H6: Perceived Ease of Use positively on influence Attitude

\section{Perceived Ease of Use and Behavioral Intention.}

Perceived ease of use is regarded as one of the determinants which affect someone to use a certain system. Perceived ease of use is defined as a level to which a person believes that in using a certain system would mentally and physically

26 Renny, Suryo Guritno, and Horniar Siringoringo, "Perceived Usefulness, Ease of use, and Attitude Towards Online Shopping Usefulness Towards Online Airlines Ticket Purchase" Social and Behavioral Sciences, 2013, pp. $81212-216$.

27 Renny, Suryo Guritno, and Horniar Siringoringo, "Perceived Usefulness, Ease of use, ...", pp. $212-216$.

${ }^{28}$ Norazah Mohd Suki and Mohd Norbayah, "Exploring The Relationship Between Perceived Usefulness, Perceived Ease Of Use, Perceived Enjoyment, Attitude And Subscribers' Intention Towards Using $3 g$ Mobile Services", Journal of Information Technology Management, Volume XXII, Number 1, 2011.

${ }^{29}$ Egbe Adewole-Odeshi, "Attitude of Students Towards E-learning in South-West Nigerian Universities: An Application of Technology Acceptance Model", Library Philosophy and Practice (e-journal), 1035, 2014. 
effortless or lack of difficulty. Perceived ease of use is the degree to which a person believes that using a particular system would be free of effort. Based on the definition above it is clear that a person is willing to use a system because of its usefulness and it is also claimed by Davis ${ }^{30}$ that easier applications have bigger potential to be accepted by users. So that we are able to conclude that if a person assumes that an application is easy to use, then that person has an intention in using that system.

According to the research conducted by Davis, by using Regression analyses, the research revealed that the two variables have a significantly greater correlation with usage behavior. In addition, the research by Alsamydai et al ${ }^{31}$ found that motivating factors which perceived ease of use is included in the factors indicated has a positive impact on the usage of mobile banking services. Therefore, based on the theory and some researches above, the hypothesis is:

H7: Perceived Ease of Use positively influences on behavioral intention.

\section{Methodology \\ Population and Sample}

The determination of the number of sample in this study is with the approach used by Cohen. It is to consider a statistical power and effect size when determined the size samples. ${ }^{32}$ The following reference is determination of sample size in the SEM model:

\section{Table 1.}

Guidance on Determining Sample Size of SEM-PLS Model

\begin{tabular}{|c|c|c|c|c|c|c|c|c|c|c|c|c|}
\hline \multirow{4}{*}{$\begin{array}{c}\text { Minimum } \\
\text { Number } \\
\text { of Arrows } \\
\text { Pointing } \\
\text { of a } \\
\text { Construct }\end{array}$} & \multicolumn{12}{|c|}{ Significance Level } \\
\hline & \multicolumn{4}{|c|}{$1 \%$} & \multicolumn{4}{|c|}{$5 \%$} & \multicolumn{4}{|c|}{$10 \%$} \\
\hline & \multicolumn{4}{|c|}{ Minimum R2 } & \multicolumn{4}{|c|}{ Minimum R2 } & \multicolumn{4}{|c|}{ Minimum R2 } \\
\hline & 0,1 & 0,20 & 0,5 & 0,75 & 0,1 & 0,25 & 0,5 & 0,75 & 0,1 & 0,25 & 0,5 & 0,75 \\
\hline 2 & 158 & 75 & 47 & 38 & 110 & 52 & 33 & 26 & 88 & 41 & 26 & 21 \\
\hline 3 & 176 & 84 & 53 & 42 & 124 & 59 & 38 & 30 & 100 & 48 & 30 & 35 \\
\hline
\end{tabular}

${ }^{30}$ D. Fred Davis, Perceived Usefulness, Perceived Ease of Use, and User Acceptance of Information Technology, MISQuarterly/September, 1998.

${ }^{31}$ M.J. Alsamyda, S.G.Yassen, H.M. Alnaimi, D.M. Dajani, I.A. Al Qirem, “The Factors Influencing...”, p. 98

32 Sholihin dan Ratmono, Analisis SEM-PLS dengsn WarpPLS 3.0, (Yogyakarta: C.V Andi, 2013), p. 13

\begin{tabular}{lllllllllllll}
\hline 4 & 191 & 91 & 58 & 46 & 137 & 65 & 42 & 33 & 111 & 53 & 34 & 27 \\
\hline 5 & 205 & 98 & 62 & 50 & 147 & 70 & 45 & 36 & 120 & 58 & 37 & 30 \\
\hline 6 & 217 & 103 & 66 & 53 & 157 & 75 & 48 & 39 & 128 & 62 & 40 & 32 \\
\hline 7 & 228 & 109 & 69 & 56 & 166 & 80 & 51 & 41 & 136 & 66 & 42 & 35 \\
\hline 8 & 238 & 114 & 73 & 59 & 174 & 84 & 54 & 44 & 143 & 69 & 45 & 37 \\
\hline 9 & 256 & 119 & 76 & 62 & 181 & 88 & 57 & 46 & 150 & 73 & 47 & 39 \\
\hline 10 & 256 & 123 & 79 & 64 & 189 & 91 & 59 & 48 & 159 & 76 & 49 & 41 \\
\hline
\end{tabular}

Source: Cohen (1992)

According to the table above the writer uses the minimum number of 109. Based on the number of arrows that is the most 7 arrows. Then the minimum value of R-Square used is 0.2 and the significance used is $5 \%$. This research is conducted in the case of Indonesian student who applying Mobile Wakaf Uang NU BTN. The reasons of choosing students are because students are considered as one of the millennial generation who often use a technology. Seeing this phenomenon, the group of teenagers is one of the potential market for producer, due to the tendency of teenagers that is usually easy to talked into advertisement, a follower, unrealistic and wasteful in spending their money. The survey questionnaire was self-administered to collect information about the determinant factors that influencing the use of cash Waqf Nahdatul Ulama by public. To measuring this information, Likert-scale based questionnaire was developed (1-Strongly Disagree and 5-Strongly Agree). The first part of the questionnaire was mainly focuses on demographic profiles of the respondents such as gender, age, marital status, education level, employment level and religion. In addition, the language used in the questionnaire was in Bahasa Indonesia. Because of the limitation of access, the samples of the present study are taken through spreading the online questionnaires through the whatsapp messanger and spreading it out to several islands in Indonesia which are Sumatera, Java, Kalimantan, Nusa Tenggara, Sulawesi, Maluku and Papua through a friend who lives in the islands.. Our target samples is actually 240 respondents distributed proportionally namely 20 respondents for each Island. However, in total about 240 surveys but only managed to get about 115 surveys which was properly filled up from seven Islands. 


\section{Findings}

The proposed model in the present study was estimated using Structural Equation Modeling (SEM). In general there are several steps that must be done if using SEM namely evaluation of measurement model, evaluation of structural model and the testing of mediation model. There are the tables of the parameter of validity and reliability test and rule of thumb for evaluation structural model.

Table 2

The parameter of Validity and Reliability Test

\begin{tabular}{|c|c|c|}
\hline $\begin{array}{l}\text { Validity and } \\
\text { Reliability }\end{array}$ & Parameter & Rule of Thumb \\
\hline \multirow[t]{2}{*}{$\begin{array}{l}\text { Convergent } \\
\text { Validity }\end{array}$} & Loading Factor & $\begin{array}{l}>0.70 \text { for The } \\
\text { Confirmatory } \\
\text { Research } \\
>0.60 \text { for The } \\
\text { Exploratory Research }\end{array}$ \\
\hline & $\begin{array}{l}\text { Average } \\
\text { Variance } \\
\text { Extracted (AVE) }\end{array}$ & $\begin{array}{l}>0.50 \text { for both the } \\
\text { confirmatory research } \\
\text { and exploratory } \\
\text { research. }\end{array}$ \\
\hline $\begin{array}{l}\text { Discriminant } \\
\text { Validity }\end{array}$ & Cross-Loading & $\begin{array}{l}\text { Loading to others } \\
\text { should be less than } \\
\text { its loading value in } \\
\text { the construct. }\end{array}$ \\
\hline \multirow[t]{2}{*}{ Reliability } & $\begin{array}{l}\text { Cronbach's } \\
\text { Alpha }\end{array}$ & $\begin{array}{l}\text { a. }>0,70 \text { for the } \\
\text { Confirmatory Research } \\
\text { b. >0,6 still accepted } \\
\text { for the Exploratory } \\
\text { Research }\end{array}$ \\
\hline & $\begin{array}{l}\text { Composite } \\
\text { Reliability }\end{array}$ & $\begin{array}{l}\text { a. }>0,70 \text { for } \\
\text { the Confirmatory } \\
\text { Research b. }>0,6 \text { still } \\
\text { accepted for } \\
\text { Exploratory Research }\end{array}$ \\
\hline
\end{tabular}

Source:Chin (1998) and Ghazali (2015, p. 76)

Table 3

Rule of Thumb for Evaluation Structural Model

\begin{tabular}{ll}
\hline \multicolumn{1}{c}{ Criteria } & \multicolumn{1}{c}{ Rule of Thumb } \\
\hline R-square & $\begin{array}{l}0,75,0,50 \text { and } 0,25 \text { shows strong, } \\
\text { moderate and weak mode }\end{array}$ \\
\hline Effect Size & $\begin{array}{l}0,02,0,15 \text { and } 0,35 \text { (small, moderate } \\
\text { and big) }\end{array}$ \\
\hline Significance level & $5 \%(0,05)$ \\
\hline
\end{tabular}

Source: Sholihin, 2013, p. 16

\section{Descriptive Analysis}

In this study, the descriptive statistics of the study will be displayed. The table below resumes the descriptive of the samples in the research based on gender, age, marital status, educational level, and income level.

Table 4

Descriptive Statistics of the Samples $(n=115)$

\begin{tabular}{|c|c|c|c|}
\hline No & Categories & Descriptions & Total \\
\hline \multirow[t]{3}{*}{1} & Gender & Male & 53 \\
\hline & & Female & 62 \\
\hline & & & 115 \\
\hline \multirow[t]{4}{*}{2} & Age & $15-20$ & 23 \\
\hline & & $20-25$ & 88 \\
\hline & & $>25$ & 4 \\
\hline & & & 115 \\
\hline \multirow[t]{3}{*}{3} & Marital Status & Single & 115 \\
\hline & & Married & - \\
\hline & & & 115 \\
\hline \multirow[t]{6}{*}{4} & Educational Level & SD & - \\
\hline & & SMP & - \\
\hline & & SMA/SMK & 90 \\
\hline & & S1 & 24 \\
\hline & & S2 & 1 \\
\hline & & & 115 \\
\hline \multirow[t]{5}{*}{5} & Income Level & $<$ Rp500.000 & 69 \\
\hline & & Rp500.000 -Rp1000.000 & 21 \\
\hline & & $\begin{array}{l}\text { Rp1000.000 - } \\
\text { Rp1.500.000 }\end{array}$ & 17 \\
\hline & & $>$ Rp1.500.000 & 8 \\
\hline & & & 115 \\
\hline
\end{tabular}

Source: Processed Data, 2018

According to the table 4.1 above, the samples are predominantly female accounted $62 \%$. The next is the age of the respondents is predominantly around 20-25, it is presumed that the respondents are still young and it shows that the range of the age is the millennial generation. This study also shows the last of educational level of the respondents that is the greatest one is graduated from SMA/SMK accounted $90 \%$, which means they are still studying in bachelor degree and most of them are single. The result of the study also indicates that the highest income level of respondents is less than Rp 500.000 (<Rp500.000) whether from their 
parents, working a part-time job, or others. In addition, according to the table 4.2 shows that most of the samples are predominantly from Java Island accounted 83 students, it is an indication that most of the students that answered the questionnaires are from Java.

\section{Results of Hypothesis Testing}

The last step of the evaluation of structural model is significance testing done by seeing the significance value through the testing of bootstrapping. The significance valued used in the present study is 0.5 (5\%). Before conducting the significance testing the author would like to display the output of PLS Algorithm and bootstrapping. The output of PLS Algorithm is used for seeing the path coefficient among latent variables and the output of bootstrapping is used for seeing t-statistic.

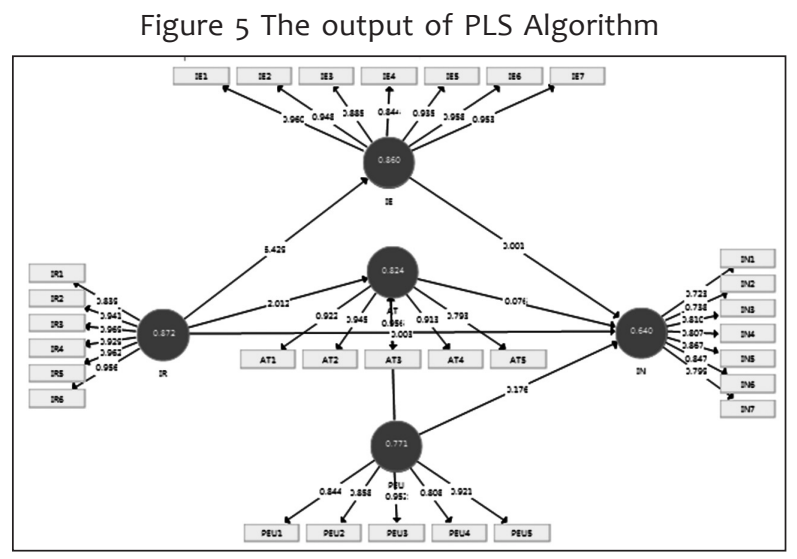

Source: Processed Data, 2018

Figure 6 The output of Bootstrapping

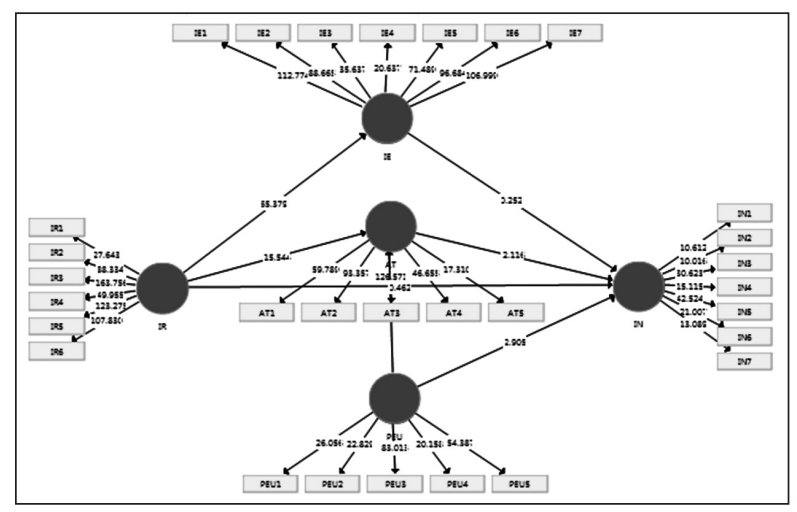

Source: Processed data, 2018

According to the figure 4.1 and 4.2 we can see the path coefficient and t-statistic directly.
However, the author would like to display in the form of table below.

Table 7 Path Coefficient and P-value

\begin{tabular}{ccc}
\hline & Original Sample (0) & P Values \\
\hline AT $>$ IN & 0.446 & 0.026 \\
\hline IE $>$ IN & 0.068 & 0.792 \\
\hline IR $>$ AT & 0.783 & 0.000 \\
\hline IR $>$ IE & 0.93 & 0.000 \\
\hline IR $>$ IN & -0.121 & 0.642 \\
\hline PEU $>$ AT & 0.172 & 0.006 \\
\hline PEU $>$ IN & 0.388 & 0.003 \\
\hline *P-value 0.05 (5\%) & & \\
\hline
\end{tabular}

Source: Processed Data, 2018

\section{Hypotheses 1}

H1= Islamic Religiosity Significantly Influences Attitude.

According to the table above the p-value of IR to AT is 0,000 and the path coefficient is 0.783 because of p-value is less than 0.05 or $p$-value $<0.05$ so that the $\mathrm{H} 1$ is accepted. It means that Islamic Religiosity significantly influences attitude.

\section{Hypotheses 2}

H2=Islamic Religiosity Significantly Influences Islamic Egalitarianism

According to the table above the p-value of IR to IE is 0.000 and the path coefficient is 0.93 because of p-value is less than 0.05 so that the $\mathrm{H}_{2}$ is accepted which means that Islamic rreligiosity significantly influences Islamic Egalitarianism.

\section{Hypotheses 3}

$\mathrm{H}_{3}=$ Islamic Religiosity Significantly Influence Intention

On this hypothesis the path coefficient value and $\mathrm{p}$-value are not used in the table above, because the value on the table is the value that has been entered by moderating variables. So that it is required to examine without other variables. 
Figure 8 PLS Algorithm

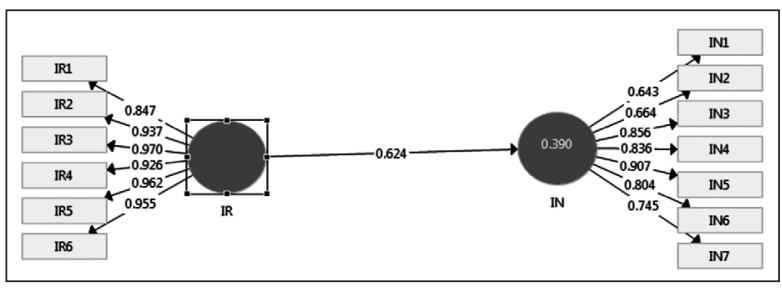

Source: Processed Data, 2018

Figure 9 Bootstrapping

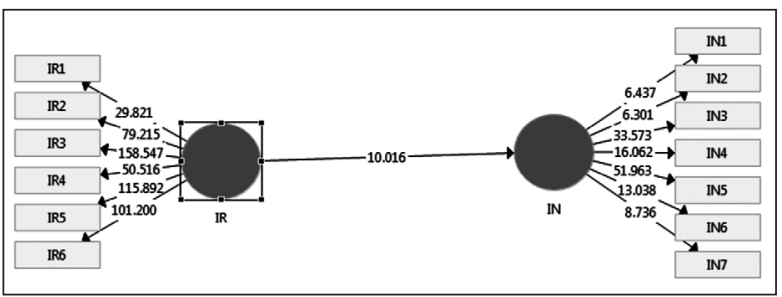

Source: Processed Data, 2018

Table 10 Path coefficient and P-value

\begin{tabular}{ccc}
\hline & Original Sample (O) & P Values \\
\hline IR $>$ IN & 0.624 & 0.000 \\
\hline
\end{tabular}

Source: Processed Data, 2018

According to the table above we can see that $\mathrm{p}$-value is 0.000 and Path Coefficient is 0.624 because of $p$-value is less than 0.05 or $p$-value < 0.05 so that the $\mathrm{H}_{3}$ is accepted which means that Islamic Religiosity significantly influences Intention.

\section{Hypotheses 4}

H4= Islamic Egalitarianism Significantly Influence Intention

According to the table $4.9 \mathrm{p}$-value is 0.792 and path coefficient is 0.068 because of $p$-value is more than 0.05 so that $\mathrm{H}_{4}$ is rejected which means that Islamic Egalitarianism does not significantly influence intention.

\section{Hypotheses 5}

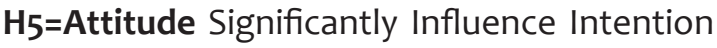

According to the table $4.9 \mathrm{p}$-value is 0.026 and path coefficient is 0.446 because of $p$-value is less than 0.05 or $p$-value $<0.05$ so that $\mathrm{H}_{5}$ is accepted. Which means that attitude significantly influence intention.

\section{Hypotheses 6}

\section{H6= Perceived Ease of Use Significantly Influence} Attitude

According to the table $4.9 \mathrm{p}$-value is 0.006 and path coefficient is 0.172 because of $\mathrm{p}$-value is less than 0.05 or $\mathrm{p}$-value $<0.05$ so that $\mathrm{H} 6$ is accepted which means that perceive Ease of Use significantly influence attitude.

\section{Hypotheses 7}

\section{H7=Perceived Ease Of Use Significantly Influence Intention}

The same way as the third hypothesis, p-value and path coefficient on the seventh hypothesis are not using on the table 4.9 because the value on the table are the value that has been entered by moderating variables. So that it is required to examine without other variables.

Figure 11 PLS Algorithm

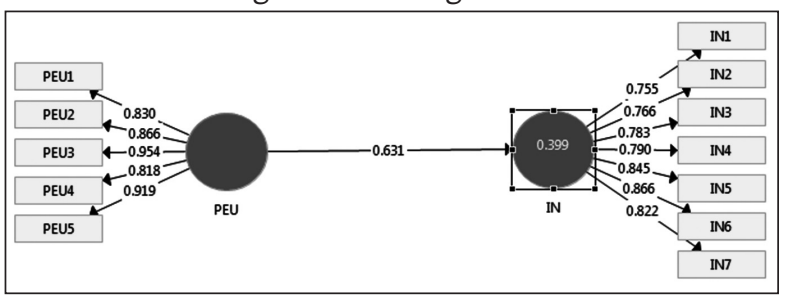

Sources: Processed Data, 2018

Figure 12 Bootstrapping

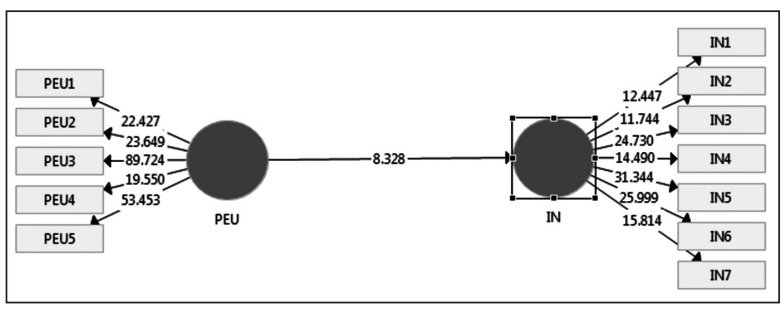

Sources: Processed Data, 2018

Table 13 Path Coefficient and T-Statistic

\begin{tabular}{lll}
\hline & Original Sample (0) & P Values \\
\hline PEU $>$ IN & 0.631 & 0.000 \\
\hline
\end{tabular}

Source: Processed Data, 2018

According to the table $4.11 \mathrm{p}$-value is 0.000 and path coefficient is 0.631 because of $p$-value is less than 0.05 so that $\mathrm{H} 7$ is accepted which means that perceived ease of use significantly influences intention. 


\section{The Testing of Mediation Effect}

The next step is testing of mediation effect, because the model used in the present study has mediation effect, namely Islamic Religiosity through attitude and Islamic Egalitarianism and Perceived Ease of Use through Attitude. In the Smart PLS 3.0 the mediation effect testing using the procedure by Baron and Kenny. There are several steps of model to measure the mediation effect, namely:

1. The first model is to examine the influence of exogenous variables $(X)$ on endogenous variables $(\mathrm{Y})$ and significantly on $\mathrm{p}$-value $5 \%$. According to the explanation on the hypothesis 3 and 7 the value of $p$-value is $<0.05$ and the path coefficient is accounted $0.624,0.631$ which means that it has filled the first requirement.

2. The second model is to examine the influence exogenous variable $(X)$ toward Mediation Variable (M) and significantly on p-value $5 \%$. In the present study the model has 2 mediation variables, namely attitude and Islamic Egalitarianism that have been explained in the hypothesis 1,2 and 6 , for in the hypothesis 1 the $p$-value for IR to AT is less than 0.05 ( $p$-value <0.05) which is being accepted and for the hypothesis 2 the $\mathrm{p}$-value for IR to IE is less than 0.05 ( $\mathrm{p}$-value $<0.05$ ) which is being accepted while in the hypothesis $6 \mathrm{p}$-value for PEU to AT is 0.006 which is being accepted and it is an indication that for AT (attitude) it does fill the second requirement, for IE (Islamic Egalitarianism) it does fill the second requirement.

3. The third model is to examine simultaneously the influence of exogenous variable toward mediation (M) and toward endogenous variable $(Y)$. In the last step of mediation effect testing expected that the influence of exogenous variable $(X)$ on endogenous variable $(Y)$ not to be significant, while the influence of mediation $(M)$ on endogenous (Y) significantly on p-value $5 \%$

In this case the $p$-value used is the value on the table 4.9, because the value in the table has mediation variable already. The table $\mathrm{p}$-value for IR to IN (IR->IN) is more than 5\% (0.05) which is 0.642 (>0.05). It means that for IR to IN (IR->IN) it has filled the third requirement and PEU to IN (PEU $\rightarrow$ IN) is less than 0,05 which is $0.003(<0.05)$ which means that for PEU it has not filled the third requirement. It is an indication that attitude and Islamic Egalitarianism fully mediate the relationship between Islamic Religiosity and Intention. While attitude partly mediate the relationship between Islamic Religiosity and Intention. The last step is to see the coefficient and significance of each variable using mediation variable $(M)$. It can be seen by seeing the value of indirect effect coefficient and significance on p-value $5 \%$ that exist in the program of SmartPLS 3.0.

Table 14 Indirect Effect

\begin{tabular}{lccc}
\hline & $\begin{array}{c}\text { Original Sample } \\
(0)\end{array}$ & $\begin{array}{c}\text { T Statistics } \\
(|\mathrm{O} / \mathrm{STDEV}|)\end{array}$ & P Values \\
\hline AT $>$ IN & & & \\
\hline IE $>$ IN & & & \\
\hline IR $>$ AT & & & \\
\hline IR $>$ IE & & & \\
\hline IR $>$ IN & 0.413 & & \\
\hline PEU $>$ AT & & & \\
\hline PEU $>$ IN & 0.077 & & \\
\hline SOurce PrOcessed & & & \\
\hline
\end{tabular}

Source: Processed Data, 2018

According to the table above, $\mathrm{p}$-value for IR to IN is 0.052 and the path coefficient is 0.413 which means that the mediation model of the influence of Islamic Religiosity on Intention through attitude and Islamic Egalitarianism is rejected and p-value for PEU to IN is 0.034 and the path coefficient is 0.077 which means that the mediation model of the influence of Perceived of Ease of Use through attitude is accepted.

\section{Conclusion and Discussion Discussion}

The Influence of Islamic Religiosity on Attitude

Religiosity is considered as a faith in God and pursuing a path that is commanded by God. Johnson et al said that Individuals with higher levels of religiosity maintain behavioral patterns that are expected to be guided by sanctions 
derived from religion ${ }^{33}$. Religiosity is a spiritual attitude of every human in God. Religiosity and a religion cannot be separated. A religion shows an institution which straighten up how to worship God, while religiosity shows a quality of a person who has a religion. Ajzen and Fishbein assumed that religion is one of the background factors that may influence the consumer attitude and subjective norm ${ }^{34}$

According to the study conducted by Sakti et al., it revealed that religiosity does influence the attitude and the study conducted by Graafland entitled "Religiosity, Attitude, and the Demand for Socially Responsible Products" showed that Christian religiosity, indeed, increases positive attitude towards SR products, except for the Orthodox Protestant affiliation. Based on the theory above we can conclude that Islamic Religiosity of someone is able to influence how a person to act and assume something.

The result of the present study showed that Islamic Religiosity positively influences on attitude. This is based on the p-value 0.000 and path coefficient 0.783 . It means that Islamic Religiosity of student influences the attitude of student to contribute to cash waqf.

\section{The Influence of Islamic Religiosity and Islamic Egalitarianism}

Egalitarianism as a doctrine that there is an intrinsic value in the equal distribution of intrinsically good things. Simply put, the concept personifies the disposition of man who gives priority for making the badly-off into well-off. Based on the theories above we can see that egalitarianism is a doctrine that believes people are equal and equal in distributing goods. This is explained in the Qur'an, Allah swt said that:

"O mankind! We have created you from a male and a female and made you into nations and tribes, that you man know one another. Verily, the most honorable of you with Allah is that (believer) who has At-Taqwa (one

\footnotetext{
33 Hamid Rizal, dan Hanudin Amin, "Perceived ihsan, Islamic egalitarianism...", pp 669-665.

34 Johan Graafland, "Religiosity, Attitude, and the Demand for Socially Responsible Products" Journal Business Ethics, 2017, 144:121-138.
}

the Muttaqun (the pious). Verily, Allah is Allknowing, All-Aware" (Al-Hujurat [49]: 13).

Marlow said that some of aspects of egalitarianism or response to it and are compatible with the interpretation that the Islamic egalitarian ethos might have been understood in the early period to have had both religious and social significance ${ }^{35}$. According Marlow's statement we are able to predict that egalitarianism is associated to religious and social. If a person is religious in Islam that person has a tendency to be an egalitarian because he or she would follow the rule and believe the teaching in Islam that Islam views all people are the same.

The result of the study showed that Islamic religiosity positively influences on Islamic egalitarianism. It is based on the p-value 0.000 and path coefficient 0.93 . This means that Islamic religiosity of a student influences on Islamic egalitarianism of a student to contribute to cash waqf. It is related to the statement of Marlow that "the Islamic egalitarian ethos might have been understood in the early period to have had both religious and social significance."

\section{The Influence of Islamic Religiosity and Intention to Contribute to Cash Waqf}

Intention is one of the important things in Islam. It plays an important role to seeking the reward from Allah swt. Intention is one of the main determinants which influence the behavior. It indicates that people are willing to try and, plan, and utilize a certain opportunity in order to perform the behavior ${ }^{36}$. Religiosity is considered as a faith in God and pursuing a path that is commanded by God. Johnson et al said that individuals with higher levels of religiosity maintain behavioral patterns that are expected to be guided by sanctions derived from religion ${ }^{37}$.

\footnotetext{
35 Louise Marlow, Hierarchy and Egalitarianism in Islamic Thought, (Cambrigde University Press, 1997), p. 13

${ }^{36}$ Amirul Faiz Osman, Muh, Mustafa Umar dan Fadhil, Aimin, “Factor Influencing ...", 2015.

37 Hamid Rizal, dan Hanudin Amin, "Perceived ihsan, Islamic egalitarianism ...", pp 669-685.
} 
The study as conducted by Rizal and Amin $^{38}$ stated that the three variables in the study have a significant relationship on cash waqf contribution. If a person is a muslim, he or she has a tendency to contribute to cash waqf, because waqf is one of the main charity in Islam. So that most of people are willing to contribute to cash waqf to get a reward in hereafter.

The result of the study shows that Islamic religiosity positively influences on Intention. It is based on p-value 0.000 and path coefficient 0.624 . It is an indication that Islamic Religiosity of a student influences on Intention of a student to contribute to cash waqf. This is related to the several previous researches that Islamic Religiosity influence on intention to contribute to cash waqf and also it is related to the statement of Johnson et al., that individuals with higher levels of religiosity maintain behavioral patterns that are expected to be guided by sanctions derived from religion.

\section{The Influence of Islamic Egalitarianism and Intention to Contribute to Cash Waqf}

Egalitarianism is a concept that assumes all people are equal. The idea of egalitarianism is rooted from the principle of justice; Rawls ${ }^{39}$ said that the principles of justice are:

"Each person is to have an equal right to the most extensive basic liberty compatible with a similar liberty for others and social and economic inequalities are to be arranged so that they are both reasonably expected to be to everyone's advantage and attached to positions and offices open to all."

The result of the study showed that Islamic egalitarianism negatively influences on intention to contribute to cash waqf. It is based on the p-value 0.792 and path coefficient 0.068 . It means that Islamic egalitarianism of a student does not influence on Intention to contribute to cash waqf. This research is different with the research of Rizal and Amin which has the result that Islamic Egalitarianism related to the contribution of cash waqf.

38 Hamid Rizal, dan Hanudin Amin, "Perceived ihsan, Islamic egalitarianism...", p. 669-685.

39 John Rawls, “An Egalitarian Theory ...", p. 78.

\section{The Influence of Attitude on Intention to Contribute} to Cash Waqf

According to Ajzen ${ }^{40}$, the concept of attitude has been the focus of attention in explanation of human behavior offered by social psychologist. Attitude is one of the elements in TPB Theory which is indicated associated with behavioral intention. In general, the more favorable a person's attitude towards behavior, the more likely it is likely the person will want to engage in the behavior" ${ }^{41}$. The research conducted by Pitchay et $\mathrm{al}^{42}$., found that the attitude of Muslim employees has more influence compared to subjective norms. Exploring the patterns and antecedents of charitable giving among muslim community in Malaysia showed that attitude and perceived behavioral control are the significant influential factors to the giving intention. The more positive the attitude the greater is the intention. It is because if a person has a good attitude to engage in behaviors, the more likely that person has an intention to behave.

The result of the study showed that attitude positively influences on intention to contribute to cash waqf. It is based on the p-value 0.026 and path coefficient 0.446 . It is an indication that the attitude of a student influences on the intention of a student to contribute to cash waqf through the application of Mobile Wakaf NU BTN.

\section{The influence of Perceived Ease of Use on Attitude}

According to Davis perceived ease of use is the degree to which the individual users perceive that their use of the target system would be mentally and physically effortless ${ }^{43}$. The study conducted by Ardana, Kertahadi, Azizah showed that positive effect between usefulness, ease of use, compatibility, risk variables on mobile banking user attitude. The more positive of people assuming that a certain system is easy

${ }^{40}$ Icek Ajzen, Attitude, Personality and Behavior, (New York: Open University Press, 2005), p.1

${ }^{41}$ Amirul Faiz Osman, "An analysis of cash waqf...", 2014.

${ }^{42}$ Ptchay, Anwar Allah, Meera, Ahmed Kameel Mydin and Saleem Muh Yusuf, “Factors Influencing...

${ }^{43}$ Cheng-Chang (Sam)Pan et al., "students's perceived ease of use of an elearning management system: an exogenous or endogenous variable?," j. Educational computing research, 2005, Vol. 33 , No. 33, pp. 285-307. 
to use, the more likely the people would engage in using that system. The result shows that perceived ease of use positively influence on attitude, it is based on the p-value 0.006 and path coefficient 0.172 . It is an indication that Perceived Ease of Use of a student influence on attitude of a student.

\section{The Influence of Perceived Ease of Use on Intention to Contribute to Cash Waqf}

According to Davis perceived ease of use is the degree to which the individual users perceive that their use of the target system would be mentally and physically effortless. Based on the definition above it is clear that a person is willing to use a system because of its usefulness and easy to use. The study conducted by Ardana, Kertahadi, Azizah described that there is a positive effect between usefulness, ease of use, compatibility, risk variables on mobile banking user attitude. The result of the study, on the other hand, showed that perceived ease of use positively influences on the intention to contribute to cash waqf, it is based on the p-value 0.000 and path coefficient 0.631 . It means that the perceived ease of use of the application for a student influences on intention of a student to contribute to cash waqf through the application.

\section{Conclusion}

The main objective of this research is to determine the determinants that influence on behavioral intention of Muslim students to contribute to cash waqf through mobile wakaf uang NU BTN. The results of the study show that six out of seven proposed hypotheses are positively significant yet only one which is not significant or rejected. The first hypotheses, religiosity positively influence on attitude is accepted, the second hypotheses is religiosity positively influence on Islamic egalitarianism has a positive influence, the third hypotheses is Islamic religiosity toward behavioral intention has a positive influence after being measured without other variables, the fourth hypotheses is Islamic egalitarianism as a mediating variable positively influence on intention is rejected, because the p-value is more than $5 \%(0.05)$. The fifth hypotheses is attitude as a mediating variable has a positive influence on intention is accepted while the sixth hypotheses, perceived ease of use is accepted and the last of hypotheses is perceived ease of use toward intention has a positive influence. Hence, based on the results above we have answered the research questions of the present study.

The interesting result of the study shows that the Islamic egalitarianism does not significantly affect on behavioral intention of Muslim students. Egalitarianism is defined as a sense of equality amongst people. Based on the data which are students, it is an indication that a young egalitarian does not have an intention to contribute to cash waqf. It is also presumed that if a person has less egalitarian it does not mean that person would not contribute to cash waqf. Hence, it is very important for waqf institution to promote, provide and emphasis religious awareness to the public more regarding the important of waqf. This can be done through media such as radio, Social Media, Televison etc.

In addition, the relationship between Islamic Religiosity and Attitude, Islamic Egalitarianism and Behavioral Intention is significantly influencing the intention on contributing to cash waqf. It is highly recommended to the waqf institution to plan some comprehensive goals to attract more people to use cash waqf and create a positive image about cash waqf and it can be done by spreading some information through marketing and awareness campaign especially to the young and senior citizens.

It is also the obligation for Islamic Banking to provide information more than that regarding the cash waqf through an application. This can be done by marketing from banks itself. Furthermore, the relationship between perceived of use and attitude and intention is related to each other. It is very important for the institution and Islamic Banking to provide more information about the application, because more of the millennial generations (young) tend to use an application for their daily life and activities.

\section{References}

Ajzen, Icek. Attitude, Personality and Behavior, New York: Open University Press, 2005. 
Alsamyda. M.J., Yassen, S.G., Alnaimi, H.M., Dajani, D.M., Al Qirem, I.A. "The Factors Influencing Customer Usage Of Mobile Banking Services In Jordan", International Journal of BusinessManagement \& Research Vol. 4, Issue 2, 2014.

Adewole-Odeshi, Egbe, "Attitude of Students Towards E-learning in South-West Nigerian Universities: An Application of Technology Acceptance Model", Library Philosophy and Practice (e-journal), 1035, 2014.

Glenwright, B.J \& Fowler, D.M, “Implications of Egalitarianism and Religiosity on Relationship Satisfaction", An International Journal on Personal Relationships. Interpersona, , Vol. 7, No. 2, 2013.

Graafland, Johan. "Religiosity, Attitude, and the Demand for Socially Responsible Products", Journal Business Ethics 144, 2017.

Harun,Munerah, Kamarudin, Fauzi Arif dan Zainuddin, "Cash waqf collection: any potential factors to influence it?". International Journal of Business, Economics and Law, Vol. 9, Issue 2 ISSN 2289-1552, April 2016.

Kasri, Rahmatina Awaliah, "Giving behaviors in Indonesia: motives and marketing implications for Islamic charities." Journal of Islamic Marketing Vol. 4 No. 3, 2013

Kachkar, Omar Ahmad. "Towards the establishment of cash waqf microfinance fund for refugees", ISRA International Journal of Islamic Finance, Vol. 9 Issue: 1, 2017.

Krysinska, Karolina, Roover, K.D,. Bouwes, J,. Ceulemans, Corveleyn, Duriez, Hutsebaut, Pollefeyt, "Measuring Religious Attitudes in Secularized Western European Context: A Psychometric Analysis of the Post-Critical Belief Scale", The International Journal for the Psychology of Religion, 24:263-281, 2014.

Marlow, Louise, Hierarchy and Egalitarianism in Islamic Thought, Cambrigde University Press, 1997.

Mochtar, Moh Zulfakhairi, "Perceptions of Universiti Sains Malaysia Muslim Staff on Factors Influencing theirlntention to Perform Cash Waqf" , Journal of Islamic Studies and Culture, Vol. 4, No. 2, December 2016.

Osman, amirul faiz, "an analysis of cash waqf participation among youngintellectuals", International Academic Conference, Istanbul, ISBN 978-80-87927-00-7, IISES, 2014

Osman, Amirul Daiz, Muh, Mustafa Umar dan Fadhil, Aimin, “Factor Influencing Cash Waqf Giving Behavior:a Revised Theory of Planned Behavior" GBSE Journal, 2015.

Ptchay, Anwar Allah, Meera, Ahmed Kameel Mydin dan Saleem Muh Yusuf, "Factors Influencing the Behavioral Intentions ofMuslim Employees to Contribute to Cash-WaqfThrough Salary Deductions". JKAU: Islamic Econ., Vol. 28 No. 1, 2015.

Pan Cheng-Chang (Sam) et al., "Students's Perceived Ease of Use of an Elearning Management System: an Exogenous or Endogenous Variable?", Educational Computing Research, Vol. 33, No. 3 285-307, 2005.

Rizal, Hamid dan Amin, Hanudin,"Perceived ihsan, Islamic egalitarianism and Islamic religiosity towards charitable giving of cash waqf",Journal of Islamic Marketing, Vol. 8 Issue: 4, pp.669-685, 2017.

Renny, Guritno, Suryo, and Siringoringo, Horniar, "Perceived Usefulness, Ease of use, and Attitude Towards Online Shopping Usefulness Towards Online Airlines Ticket Purchase", Journal of Social and Behavioral Sciences 81 212 - 216, 2013.

Rawls, John, An Egalitarian Theory of Justice. Cambridge, Mass: Harvard University Press, 1971.

Sholihin dan Ratmono, Analisis SEM-PLS dengsn WarpPLS 3.0, Yogyakarta: C.V Andi, 2013.

Sakti, Muh R.P, Thaker Hassanudin, Qoyum, Abdul dan Qizam, Ibnu, "Determinants of cash waqf contribution in KlangValley and Slangor:A SEM Approach" Journal of Islamic Monetary Economics and Finance, Vol. 2, No 1, 2016

Suki, Norazah Mohd and Suki, Norbayah Mohd, "Exploring The Relationship Between Perceived Usefulness, Perceived Ease Of Use, Perceived Enjoyment, Attitude And Subscribers' Intention Towards Using $3 g$ Mobile Services". Journal of Information Technology Management, Volume XXII, Number 1, 2011.

U.S. Commission on international religious freedom. 2017. Annual report. 